\title{
PROSES BERPIKIR SISWA LEVEL DEDUKSI INFORMAL DALAM MENYELESAIKAN MASALAH LUAS PERMUKAAN LIMAS DAN PRISMA BERDASARKAN TAHAPAN POLYA
}

\author{
Titis Sahrita ${ }^{1}$, Susanto ${ }^{2}$, Erfan Yudianto ${ }^{3}$, Titik Sugiarti4, \\ Toto' Bara Setiawan $^{5}$ \\ 1,2,3,4,5Fakultas Keguruan dan Ilmu Pendidikan, Universitas Jember \\ email korespondensi: erfanyudi@unej.ac.id
}

Diterima : (04-05-2021), Revisi: (23-05-2021), Diterbitkan : (25-05-2021)

\begin{abstract}
ABSTRAK
Penelitian ini bertujuan untuk mendeskripsikan proses berpikir geometri siswa dalam menyelesaikan masalah luas permukaan limas dan prisma melalui tahapan Polya. Subjek penelitian ini adalah dua siswa yang berada pada level deduksi informal di SMPN 3 Jember. Siswa diberikan tes tentang luas permukaan limas dan prisma, dilanjutkan dengan wawancara. Jenis penelitian ini adalah deskriptif kualitatif. Hasil penelitian menunjukkan bahwa proses berpikir siswa mengalami kondisi disequilbrium dan equilbrium dengan melalui asimilasi dan akomodasi dalam setiap tahap pemecahan masalah luas permukaan limas dan prisma, serta siswa juga memenuhi indikator kemampuan berpikir geometri Van Hiele pada level deduksi informal. Siswa memahami kondisi dan fakta masalah, mengidentifikasi himpunan sifat-sifat bangun yang berbeda-beda untuk mengkarakterisasi kelas dan mengaitkan antar karakteristik pembentuk konsep, menentukan rumus yang tepat dalam pemecahan masalah, dan memecahkan masalah dengan menekankan pada pentingnya sifat gambar dan relasinya.

Kata kunci : Berpikir deduksi informal, tahapan Polya, luas permukaan limas dan prisma
\end{abstract}




\begin{abstract}
This study aims to describe the geometry students thinking process on resolving problems of pyramid and prism surface area through Polya stages. The subjects of this study were two students who were at the informal deduction level of junior high school in SMPN 3 Jember. Students have given test about the surface area of pyramid and prism, followed by interviews. This research type is called descriptive qualitative.The results showed that the students' thought processes experienced disequilbrium and equilbrium conditions through assimilation and accommodation in each stage of solving the problem of the surface area of the pyramid and prism, and the students also met the indicators of Van Hiele's geometric thinking skills at the level of informal deduction. They are able to understand the condition and facts of the problem, able to identify different sets of waking traits to characterize the wake class and associate between the characteristics of the concept shaper, determine the right formula in problem solving, and solve problems by emphasizing the importance of the properties of images and their relationships.
\end{abstract}

Key words:Think informal deduction, Polyastages, pyramid and prism surface area

\title{
Pendahuluan
}

Berpikir merupakan proses yang dijalankan oleh akal untuk mengkoordinasikan pengetahuan-pengetahuan dengan cara baru, misalnya dengan memecahkan sebuah permasalahan tertentu. Pada kurikulum sekolah, geometri menjadi salah satu cabang ilmu matematika yang cukup mendominasi. Berpikir geometri digunakan untuk menyelidiki dan menyelesaikan masalah, serta membangun relasi antara matematika dengan kehidupan sehari-hari (Fabiyi, 2017; Jayathirtha, 2018; Ramdani, 2012). Saat menyelesaikan masalahgeometri, memuat unsur penerapan visualisasi, kemampuan spasial, dan pola pemodelangeometri (Setyawan, 2019).

Kemampuan berpikir siswa dalam menyelesaikan permasalahan di bidang geometri dapat ditinjaudari teori Van Hiele. Tingkatan kemampuan berpikir menurut teori Van Hiele yaitu : level 0 (visualisasi), level 1 (analisis), level 2 (deduksi informal), level 3 (deduksi), dan level 4 (rigor)(Walle et al., 2016; Asemani et al., 2017; Yudianto et al., 2018; Hadi, 2019). Deskriptor level deduksi informal dalam teori Van Hiele yaitu siswa dapat memformulasikan dan menggunakan definisi, menentukan himpunan dari sifat-sifat bangun yang berbeda untuk mengkarakterisasi kelas bangun dan menguji bahwa karakteristik kelas bangun tersebut telah cukup, mampu mengurutkan kelas suatu bangun, menyajikan argumen secara informal, serta memecahkan masalah dengan menekankan akan pentingnya sifat-sifat dari gambar sekaligus relasinya (Muslim et al., 2017; Fitriyani et al., 2018; 
Hiele, 2000; Yudianto et al., 2019)

Dalam memecahkan suatu masalah, siswa akan mengalami kondisi disequilbrium dan equilbrium dengan melalui proses asimilasi dan akomodasi sesuai dengan teori Piaget, dimana pada teori ini lebih memusatkan pada proses berpikir siswa dan bukan hanya pada hasil. Dengan demikian proses berpikir dapat tergambar melalui semua tahap yang dilakukan dalam memecahkan masalah. Salah satu teori tentang pemecahan masalah dikemukakan oleh Polya yang biasa dikenal dengan tahapan Polya (Ayuningrum, 2017; Agostino, 2011; Polya, 2020; Yuan, 2013). Berikut ini hubungan antara proses berpikir Piaget dengan pemecahan masalah Polya.

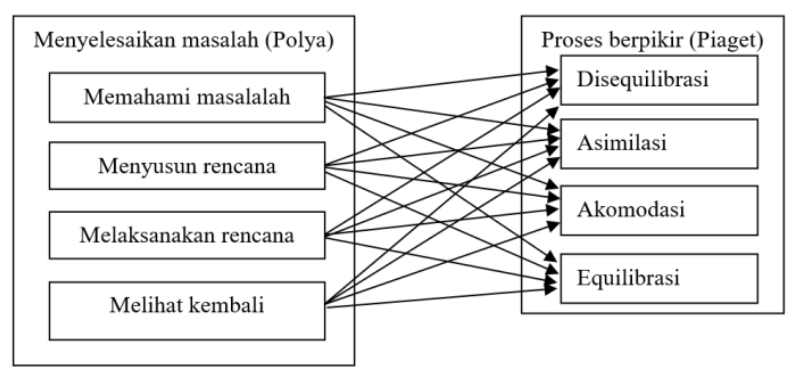

Gambar 1. Hubungan proses berpikir Piaget dan pemecahan masalah Polya

Bangun ruang menjadi pokok bahasan penting dalam geometri. Masih banyak siswa yang menganggap bahwa kubus dan balok tidak dapat dikatakan sebagai prisma, sedangkan limas dapat dikatakan prisma. Kubus dan balok memiliki kesamaan ciri-ciri dengan prisma tegak, antara lain : sisi yang berhadapan kongruen dan sejajar, serta rusuk tegaknya tegak lurus dengan bidang alasnya. Balok adalah suatu bangun ruang yang dibatasi oleh enam sisi persegi panjang atau tiga pasang sisi berhadapan yang kongruen berbentuk persegi panjang. Luas permukaan balok dan kubus dapat diperoleh dari formula luas permukaan prisma tegak segi empat, yaitu jumlah luasan dari enam sisi persegi panjang yang membatasi. Pokok bahasan luas permukaan bangun ruang ini dapat menggali proses berpikir serta kemampuan geometri siswa dalam memahami sifat-sifat dan relasi antar bangun ruang yang selanjutnya digunakan dalam penyelesaian masalah. Berdasarkan latar belakang yang telah diuraikan, penelitian ini ditujukan untuk mengetahui bagaimana proses berpikir siswa level deduksi informal dalam menyelesaikan masalah luas permukaan limas dan prisma. 


\section{Metode Penelitian}

Jenis penelitian yang digunakan dalam hal ini adalah penelitian kualitatif deskriptif. Subjek dari penelitian sebanyak dua orang. Metode pengumpulan data diawali dengan memberikan tes kemampuan geometri untuk mendapatkan subjek penelitian dengan level deduksi informal melalui googleform. Setelah itu diberikan tes pemecahan masalah luas permukaan limas dan prisma untuk mengetahui proses berpikir siswa dalam penyelesaian masalah berdasarkan tahapan Polya. Selanjutnya dilakukan wawancara guna memperjelas dan mendukung hasil tes siswa. Pelaksanaan tes dan wawancara dilakukan secara online melalui zoom. Metode analisis yang digunakan adalah deskriptif kualitatif dimana data yang diperoleh dianalisis secara kualitatif, diuraikan secara deskriptif, kemudian disajikan dalam bentuk narasi. Penentuan level berpikir van Hiele menggunakan tes dan kriteria penskoran yang dikembangkan oleh Usiskin (1982). Dua siswa dipilih menjadi subjek karena memiliki kemampuan komunikasi yang baik dan pada level deduksi informal. Subjek dikodekan S1 sebagai subjek 1 dan S2 sebagai subjek 2. Tahapan dalam menganalisis data adalah reduksi data seperti merangkum, memilih hal-hal pokok, dan memfokuskan pada hal-hal penting dari suatu data, selanjutnya penyajian data yaitu data diklasifikasi berdasarkan subjek penelitian, dan yang terakhir yaitu penarikan kesimpulan.

Instrumen yang digunakan harus melalui uji validasi oleh validator. Validator instrumen pada penelitian ini dilakukan oleh dua dosen Program Studi Pendidikan Matematika FKIP Universitas Jember dan satu guru matematika SMPN 3 Jember. Tingkat kevalidan instrumen dijadikan sebagai penentu kelayakan instrumen untuk digunakan dalam penelitian ini. Instrumen penelitian dapat dikatakan valid dengan nilai $8 \leq V a \leq 10$. Hasil validasi instrumen tes luas permukaan limas dan prisma dan pedoman wawancara berturut-turut 9,28 dan 9,20. Hal ini menandakan bahwa instrumen tersebut telah valid sehingga dapat digunakan dalam penelitian ini.

\section{Hasil dan Pembahasan}

\section{Hasil Penelitian}

Tes pemecahan masalah luas permukaan digunakan untuk menggali proses berpikir siswa level deduksi informal adalah bangun ruang limas dan prisma yang 
berbasis kontekstual. Berikut ini adalah instrumen tes pemecahan luas permukaan limas dan prisma.

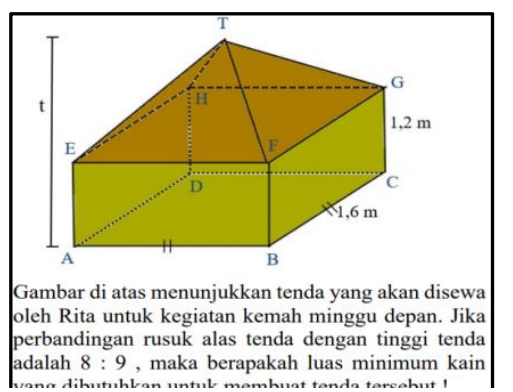

(a)

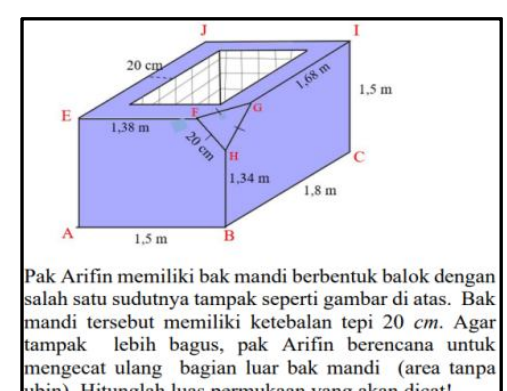

(b)

Gambar 2. Soal pemecahan masalah (a) nomor 1 dan (b) nomor 2

\section{a. Proses Berpikir S1}

\begin{tabular}{|c|c|}
\hline a.) Memanami masalah & $\begin{array}{l}\text { a) Tlemandmi masalah : } \\
\text { - Diketahui : }\end{array}$ \\
\hline - Diketahui : & - Ketebalan tepi bak mandi $=20 \mathrm{~cm}$ \\
\hline - Perbandingan rusuk alas tenda dengan tinggi = 8 : & - Panjang bak mandi \\
\hline - lebar balok $=1,6 \mathrm{~m}=160 \mathrm{~cm}$ & - Lebar bak mandi $\quad=115 \mathrm{~m}=150 \mathrm{~cm}$ \\
\hline - Tinggi balok $=1,2 \mathrm{~m}=120 \mathrm{~cm}$. & $\begin{array}{ll}\text { - Tingal bak mandi } & =115 \mathrm{~m}=150 \mathrm{~cm} \\
\text { - Panjang sisi } 6 \mathrm{H} & =20 \mathrm{~cm}\end{array}$ \\
\hline - Ditanya : & - Panjang sisi FH $=20 \mathrm{~cm}$ \\
\hline Luas minimum kain yang dibutuhkan untuk memb & - Ditanya : \\
\hline tenda tersebut? & $\begin{array}{l}\text { Luas permukaan yangakan di cat oleh } \\
\text { Pak Arifin? }\end{array}$ \\
\hline
\end{tabular}

(a)

(b)

Gambar 3. Tahap memahami masalah (a) soal nomor 1 dan (b) soal nomor 2 oleh S1 Saat memahami masalah, S1 mengalami asimilasi saat menyebutkan dengan lancar tentang data apa saja yang diketahui dan apa ditanyakan dari permasalahan. S1 juga menguraikan secara rinci permasalahan yang akan diselesaikan menggunakan kalimat argumentasi informal dengan menjelaskan bahwa pada permasalahan nomor 1 dan 2 akan ditentukan luas permukaan bangun ruang.

\begin{tabular}{|c|c|}
\hline Menyusun rencana: & Menyusun rencana \\
\hline 1.) Menentukan luas selimut bangun ruang $k e-1$, yaitu bo & -1. Memorong semua sisi balok, seningga menjadi \\
\hline 2.) Menentukan luas selimut bangun ruang $\mathrm{Ke}-2$, yaitu & $\begin{array}{l}5 \text { sisi, karena satu sisi dibawan tidak dicat } \\
\text { dan satu sisi segitiga yaitu segi tiga FGH }\end{array}$ \\
\hline limas regi empat & Menentukan luas sisi masing-masing. \\
\hline a. Menentukan tinggi tenda. & $\begin{array}{l}\text { a. Mencari luas sisi } A B E F H \\
\text { b. Mencari luas sisi } B C 16 H\end{array}$ \\
\hline b. Menentukan tinggi limas. & c. Mencari luas sisi EJIGF yang diarsir \\
\hline c. Mencari tinggi segitiga sebagai selimut limas. & d. Mencari luas sisi CDIJ \\
\hline d. Mencari tuas selimut limas segi empat. & $\begin{array}{l}\text { e. Mencari luas sisi ADEj } \\
\text { f. Mencari luas sisi segitiga FGH }\end{array}$ \\
\hline 3) Menentukan was permukaan total tenda. & 3.] Menentukan Luas permukaan total bak \\
\hline
\end{tabular}

(a)

(b)

Gambar 4. Tahap menyusun rencana (a) soal nomor 1 dan (b) soal nomor 2 oleh S1 Selanjutnya yaitu tahap menyusun rencana. S1 akan menentukan luas selimut balok dan limas segi empat. Pada permasalahan 2, S1 membagi setiap sisi bak mandi yang akan dicat untuk ditentukan luas sisinya, kemudian S1 akan menentukan luas permukaan bak mandi yang akan dicat dengan menjumlahkan semua luas sisi-sisi 
terluarnya. Selanjutnya S1 mengalami akomodasi kembali saat menyatakan bahwa badan tenda dapat dikatakan sebagai prisma tegak segi empat. S1 mengalami akomodasi dengan mengingat kembali mengenai definisi kubus, akhirnya S1 mencapai kondisi equilbrium, ditandai dengan S1 yakin bahwa balok tidak dapat dikatakan sebagai kubus. Berdasarkan yang diperoleh, S1 mengalami asimilasi saat menjelaskan alur penyelesaian beserta alasannya. S1 juga mengalami akomodasi saat ditanya susunan rencananya secara rinci. Selanjutnya mencapai kondisi equilbrium yaitu mengetahui bagaimana tahapan yang benar untuk menyelesaikan masalah.

\begin{tabular}{|c|c|}
\hline c.) Melaksanakan rencana & 2.] Menentukan luas selimut bangun ruang $k e-2$, yaitu \\
\hline 1.] Menentukan luas selimut banqun ruang ke-1, yaitu & limas segia. \\
\hline balok. & a.) Menentukan tinggi tenda. \\
\hline Selimut balok berbentuk persegi panjang $160 \mathrm{~cm} / 120 \mathrm{~cm}$, & Dalam tanapan ini, bisa menggunakan perbandingan rusuk \\
\hline jadi, untuk menentukan luas sellmut balok, menggunakan & alas tendo dengan tinggitenda. \\
\hline rumus $\Rightarrow L=P \times l$ & R.alas : T.tenda \\
\hline$L=P \times l$ & $8: 9$ \\
\hline$=160 \mathrm{~cm} \times 120 \mathrm{~cm}$ & $160 \mathrm{~cm}: P$ \\
\hline$=19200 \mathrm{~cm}^{2}$ & Untuk mencari $P$ (tinggi tenda) menggunakan atternatif : \\
\hline Balok mempunyai empat sisi persegl panjang. jadl luas & $P=\frac{160 \mathrm{~cm}}{8} \times 9$ \\
\hline selimut balok dikali empat. & $=2 \mathrm{O}_{\mathrm{mm}} \times 9$ \\
\hline Selimut $T t l=19200 \mathrm{~cm}^{2} \times 4$ & $=180 \mathrm{~cm}$ \\
\hline$=76800 \mathrm{~cm}^{2} \mathrm{ij}$ & Jadi, tinggi tenda adalah $180 \mathrm{~cm} / \mathrm{s}$ \\
\hline
\end{tabular}

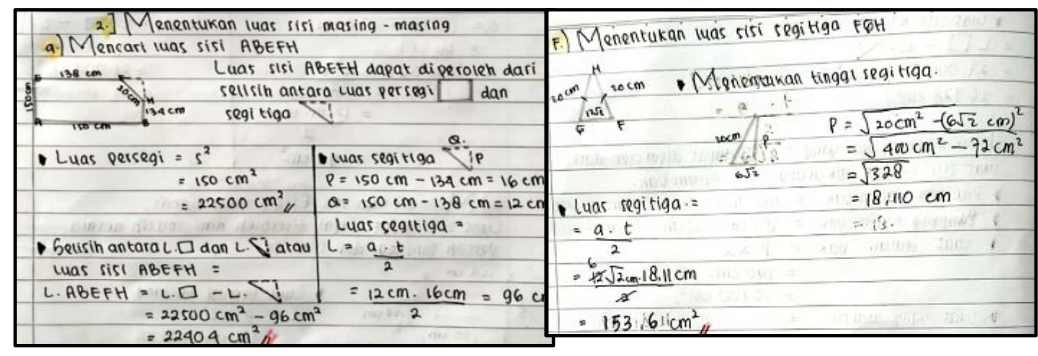

Gambar 5. Tahap melaksanakan rencana soal nomor 1 oleh S1

Berikutnya tahap melaksanakan rencana, S1 mengalami asimilasi dan akomodasi saat menentukan unsur-unsur bangun ruang yang belum diketahui. Hal ini sejalan dengan cuplikan hasil wawancara berikut.

P108: Ini tinggi segitiganya, gimana cara dapatnya? kok bisa pakai $6 \sqrt{2}$.

S108: (diam sebentar) Eee $6 \sqrt{2}$ itu...oh setengahnya FG.

Berdasarkan data di atas, S1 dikatakan berada pada kondisi equilbrium setelah mengalami serangkaian proses asimilasi dan akomodasi secara berulang. S1 dapat menjelaskan perolehan luas permukaan saat telah diketahui ukuran unsur-unsurnya dengan melakukan perhitungan, sehingga ia dapat memastikan bahwa pelaksanaan rencana yang dilakukan telah sesuai dengan rencana yang disusun, dan juga memperoleh hasil yang benar. 


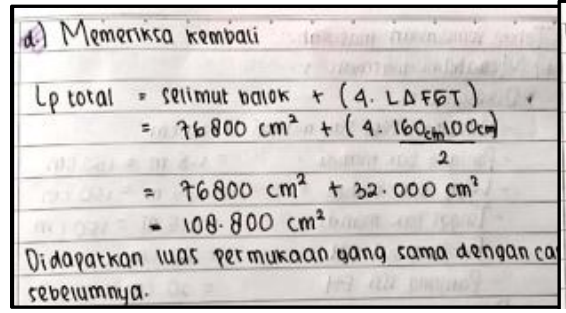

(a)

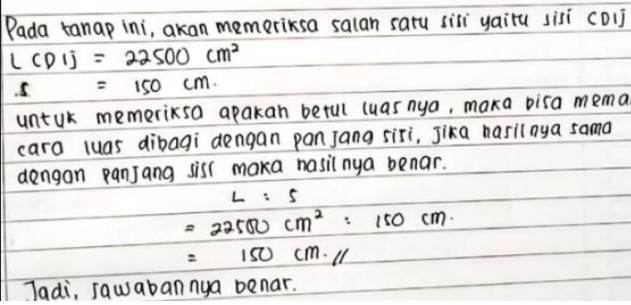

Tadi, sawaban nya benar

Gambar 6. Tahap memeriksa kembali (a) soal nomor 1 dan (b) soal nomor 2 oleh S1

Tahap yang terakhir yaitu memeriksa kembali, S1 mengalami disequilbrium saat ditanya cara lain untuk memeriksa hasil yang diperoleh. Kemudian S1 mengalami akomodasi dengan tidak langsung menjawab pertanyaan. S1 telah melakukan perhitungan ulang untuk memeriksa kembali jawaban yang diperoleh serta memeriksa dengan menghilangkan salah satu unsurnya untuk kemudian dicocokkan hasilnya. Hal ini sejalan dengan cuplikan wawancara berikut.

P109 : Gimana cara kamu memeriksa jawabanmu?

S109: Ngoreksi hitungan sama nyoba ngilangin salah satu panjang sisi di CDIJ.

P110 : Gak punya cara lain berarti ya?

S110 : Eee pakai luas trapesium dan persegi panjang tapi sepertinya lebih sulit

Berdasarkan wawancara di atas, dapat diketahui bahwa S1 mengalami asimilasi saat menjelaskan dengan penuh keyakinan bahwa langkah penyelesaian yang ia lakukan merupakan cara yang paling mudah diantara cara yang lain. Selanjutnya S1 berada pada kondisi equilbrium setelah mengalami asimilasi dan akomodasi, yaitu dapat menyatakan bahwa perhitungan jawaban yang diperoleh sudah benar.

\section{b. Proses Berpikir S2}

\begin{tabular}{|c|c|}
\hline c) memahami masalah & A) Memaham: masalah \\
\hline Diketahui : & $\begin{array}{l}\text { Diketahui: } \\
\Rightarrow \text { terdapat bqk mandi berbentuk balok } A B C h\end{array}$ \\
\hline - terdapat bangun gabungan antara balok ABCOEFGH dd & $\rightarrow$ dengapar bagian tumpul di $\mathrm{FFH}$. \\
\hline $\begin{array}{l}\text { terdapat bangun gabungan antara balok ABCU Erot a } \\
\text { limas segiempat EFGHT }\end{array}$ & $\Rightarrow$ besar $\mathrm{FH}=\mathrm{HG}=20 \mathrm{~cm}$ \\
\hline$\Rightarrow A B=B C=1,6 \mathrm{~m}$ & $\begin{array}{l}\rightarrow \text { bak mandi tersebut } \\
\Rightarrow \text { bak mandi tersebut memiliki ukuran: }\end{array}$ \\
\hline -) $C E=1,2 \mathrm{~m}$ & $\begin{array}{rl}A B & H B=1.34 \mathrm{~m} \\
E F=1.5 \mathrm{~m} & H B \mathrm{~m}\end{array}$ \\
\hline c) $A B=t=8: 9$ & $\begin{array}{l}B C=1.8 \mathrm{~m} \\
C L=1.5 \mathrm{~m}\end{array}$ \\
\hline Ditanyakan : Luas & $1 \sigma=1.68 \mathrm{~m}$ \\
\hline & Ditanya: Luas permukaan bagian lvar bak $m$ \\
\hline
\end{tabular}

(a)

(b)

Gambar 7. Tahap memahami masalah (a) soal nomor 1 dan (b) soal nomor 2 oleh S2

Pada saat memahami permasalahan nomor 1, awalnya S2 mengalami disquilbrium. Hal ini ditandai dengan kebingungan saat melihat gambar pada soal yang 
diberikan saat tes berlangsung. S2 menyatakan bahwa ia membaca ulang soal hingga benar-benar paham. Kemudian S2 mengalami akomodasi ketika menjelaskan kembali masalah yang diberikan. Hal tersebut ditandai dengan S2 diam sebentar lalu baru menjawab pertanyaan dengan cukup lancar meskipun terkadang sedikit terbata-bata. Selanjutnya mengalami asimilasi saat menunjukkan bangun ruang apa saja pada soal.

Setelah melalui asimilasi dan akomodasi, secara berulang-ulang, S2 dapat mencapai kondisi equilbrium dalam memahami maksud permasalahan nomor 1 . Hal ini ditandai dengan S2 mampu menjelaskan apa saja yang diketahui dan tidak diketahui, apa yang ditanyakan, dapat menunjukkan dengan benar bagian mana saja yang membutuhkan kain, dapat memahami kondisi dan fakta yang terdapat pada permasalahan ke dalam bentuk matematis, serta dapat menunjukkan bangun apa saja yang terdapat dalam soal dengan benar, sehingga, dapat dikatakan bahwa S2 telah memahami permasalahan nomor 1 dengan baik.

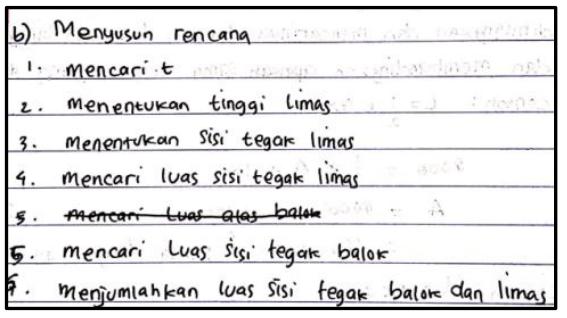

(a)

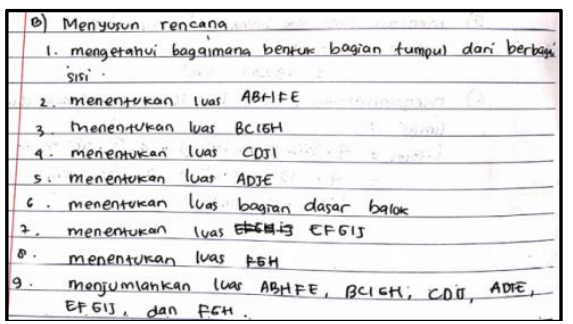

(b)

Gambar 8. Tahap menyusun rencana (a) soal nomor 1 dan (b) soal nomor 2 oleh S2

Selanjutnya tahap menyusun rencana, S2 mengalami asimilasi dan akomodasi pada permasalahan nomor 1 dan 2 saat menjelaskan secara rinci susunan rencana yang akan dilakukan. Selanjutnya S2 mengalami akomodasi saat menyatakan bahwa badan tenda dapat dikatakan sebagai bangun ruang prisma tegak segi empat, kemudian mengalami asimilasi saat diminta menjelaskan persamaan prisma tegak segi empat dan balok, serta saat menjelaskan bahwa luas permukaan balok juga bisa diperoleh dari luas permukaan prisma tegak segi empat.

Berdasarkan penjelasan di atas, S2 melakukan penyusunan rencana dengan sangat baik, ia mengalami semua rangkaian proses berpikir asimilasi dan akomodasi secara berulang hingga mencapai kondisi equilbrium yaitu dapat menjelaskan bagaimana langkah-langkah yang benar untuk menyelesaikan permasalahan, serta dapat menjelaskan relasi atau hubungan dari bangun-bangun ruang. 


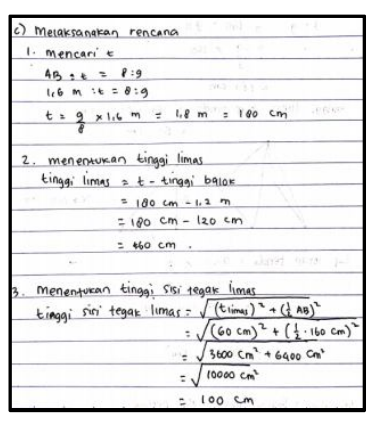

(a)

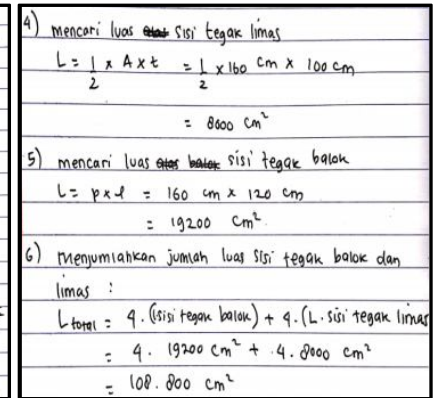

(b)

Gambar 9. Tahap melaksanakan rencana nomor 1 oleh S2

\begin{tabular}{|c|c|}
\hline - menentukan luas $E$ & menentukan luas $A D J$ \\
\hline $\begin{array}{l}F G^{2}=F H^{2}+G Y^{2} \\
F G=\sqrt{12^{2}+12^{2}}=\sqrt{144+194}=\sqrt{288}=12 \sqrt{2}\end{array}$ & $L=P \times l=1,8 \mathrm{~m} \times 1,5 \mathrm{~m}=180 \mathrm{~cm} \times 150 \mathrm{~cm}=27000 \mathrm{~cm}$ \\
\hline (misal ditengah-tengah F dan 6 terdapat titik $Z$ & 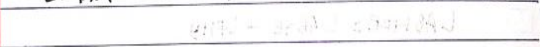 \\
\hline$F Z=12 \sqrt{2}: 2=6 \sqrt{2}$ & 6. Menentukan luas bagian dasar bak \\
\hline if $\quad \begin{aligned} 20 \mathrm{~cm} & =\sqrt{F H^{2}-F Z^{2}} \\
& =\sqrt{2 a^{2}-(6 \sqrt{2})^{2}}\end{aligned}$ & $L=p \times s=(1,8 \mathrm{~m}-40 \mathrm{~cm}) \times(1,5 \mathrm{~m}-40 \mathrm{~cm})$ \\
\hline$=\sqrt{400-72}$ & $=(180 \mathrm{~cm}-40 \mathrm{~cm}) \times(150 \mathrm{~cm}-40 \mathrm{~cm})$ \\
\hline $\begin{array}{l}=\sqrt{328} \\
=2 \sqrt{82}\end{array}$ & $=140 \mathrm{~cm} \times 110 \mathrm{~cm}$ \\
\hline$L \cdot F \bar{G} H=F G \times H Z \times \frac{1}{2}=12 \sqrt{2} \times 2 \sqrt{82} \times \frac{1}{2}$ & $=15400 \mathrm{~cm}^{2}$ \\
\hline
\end{tabular}

(a)

(b)

Gambar 10. Tahap melaksanakan rencana nomor 2 oleh S2

Tahap selanjutnya yaitu melaksanakan rencana, S2 cenderung mengalami asimilasi pada nomor 1, dan sering mengalami asimilasi dan akomodasi secara berulang pada nomor 2 . Berikut cuplikan wawancara yang sejalan dengan hal tersebut

S207: ZH ini diperoleh dari mana?

S207: ZH pakai pytaghoras dari FH sama FZ, kan Z ini titik tengah FG

P208: $\quad$ Oke, terus luasnya ini kok belum dibagi 2? Coba cek hitungannya.

S208: (diam sebentar untuk memeriksa perhitungan) hasil akhir bu?

P209: Iya, gimana ? udah bener atau ada yang salah ?

S209: Oh...ini ya bu...belum tak bagi coret ini 2 nya

Berdasarkan hasil tersebut, S2 melaksanakan rencana dengan baik. S2 dikatakan berada pada kondisi equilbrium setelah mengalami serangkaian proses asimilasi atau akomodasi secara berulang. Dalam hal ini, S2 dapat menjelaskan perolehan luas permukaan saat telah diketahui ukuran unsur-unsurnya dengan melakukan perhitungan, sehingga dapat memastikan bahwa pelaksanaan rencananya telah benar. 


\begin{tabular}{|c|c|}
\hline conton: $L=I \times A \times t$ & $\Rightarrow L=p \times e$ \\
\hline 2 & $\begin{aligned} 22500 \mathrm{~cm}^{2} & =P \times 150 \mathrm{~cm} \\
P & =50 \mathrm{~cm} \quad(\text { sama })\end{aligned}$ \\
\hline $8000=\frac{1}{2} \times A \times 100$ & $\Rightarrow H \sigma^{2}=z E^{2}+z H^{2}$ \\
\hline$=8000 \times 2: 100$ & $\begin{aligned} H G & =\sqrt{(6 \sqrt{2})^{2}+(2 \sqrt{32})^{2}} \\
& =\sqrt{12+328}\end{aligned}$ \\
\hline$=160 \mathrm{~cm}$ ( sama dengan yg diketahu & $\begin{aligned} & =\sqrt{400} \\
& =20 \text { (sama) }\end{aligned}$ \\
\hline
\end{tabular}

(a)

(b)

Gambar 11. Tahap memeriksa kembali (a) soal nomor 1 dan (b) soal nomor 2 oleh S2

Pada tahap memeriksa kembali S2 mengalami disequilbrium saat ditanya cara lain untuk memeriksa hasil yang diperoleh. Kemudian S2 mengalami asimilasi saat menjelaskan bahwa telah memeriksa dengan menghilangkan salah satu unsurnya untuk kemudian dicocokkan hasilnya. Berikut ini hasil wawancara S2 saat memeriksa kembali jawaban yang diperoleh.

P210 : Gimana cara kamu untuk memeriksa kembali jawaban yang didapat?

S210: Ngeceknya itu saya hilangkan salah satu ukuran sisinya, terus tak cocokkan dengan yang diketahui, kalau hasilnya cocok berarti sudah benar.

Akhirnya S2 berada pada kondisi equilbrium, yaitu saat menyatakan dengan yakin bahwa perhitungan jawaban yang diperoleh sudah benar.

\section{Pembahasan}

Hasil penelitian menunjukkan bahwa proses berpikir S1 dan S2 hampir sama. Tahap penyelesaian yang pertama yaitu memahami permasalahan. Kegiatan memahami masalah berupa membaca permasalahan, mencermati permasalahan, dan mengetahui apa yang disajikan dalam suatu permasalahan. Pada saat memahami masalah, siswa cukup baik saat memahami permasalahan nomor 1, namun sempat mengalami kesulitan atau berada pada kondisi disequilibrium saat memahami permasalahan nomor 2. Disequilibrium terjadi ketika informasi baru tidak dapat disesuaikan ke skema lama yang telah dimiliki siswa sehingga mengakibatkan kebingungan saat mencoba memahami masalah yang diberikan (McLeod, 2018). Selanjutnya siswa berada pada kondisi equilibrium yaitu saat mampu menyeimbangkan antara proses asimilasi dan akomodasi dalam menggunakan skema lama dan tindakan untuk skema baru, serta merespon sesuai dengan permasalahan yang diberikan (Kivkovich, 2015; McLeod, 2018; Pavlovicova \& Zahorska, 2015; Siegler et al., 2014). Saat berasimilasi, siswa melalui proses pengintegrasian informasi baru ke dalam skema yang terbentuk, sedangkan saat akomodasi, siswa mengubah skema lama menjadi skema baru untuk disesuaikan dengan informasi yang dite- 
rima.

Indikator selanjutnya merupakan deskriptor level van Hiele untuk level deduksi informal. Berdasarkan hal tersebut, siswa mampu mengenali hubungan atau relasi antar bangun ruang dengan menyatakan bahwa kubus merupakan balok dengan sisi-sisi yang kongruen, serta kubus dan balok merupakan prisma tegak segi empat. siswa melakukan identifikasi himpunan sifat-sifat bangun yang berbeda untuk mengkarakterisasi kelas bangun karena telah mengetahui hubungan antar sifat-sifat dalam suatu bangun ruang tersebut Hal tersebut sesuai dengan hasil penelitian yang dilakukan oleh (Falupi \& Widadah, 2016; Rinaldi et al., 2019; Muslim et al., 2017; Setyawan, 2019; Pressley 2010).

S1 dan S2 pada tahap memahami masalah, menyusun rencana, melaksanakan rencana, serta memeriksa kembali hasil penyelesaian masalah yang dilakukan mengalami empat proses berpikir yang dikemukakan oleh Piaget yaitu disequilibrium, asimilasi, akomodasi, dan equilibrium. Sesuai dengan deskriptor van Hiele untuk level deduksi informal yaitu siswa telah mampu memformulasikan dan menggunakan definisi, mengidentifikasi himpunan sifat-sifat bangun yang berbeda untuk mengkarakterisasi kelas bangun dan menguji bahwa karakteristik kelas bangun tersebut telah cukup, dapat mengurutkan kelas suatu bangun, menyajikan argumen secara informal, serta menyelesaikan masalah dengan menekankan pada pentingnya sifat-sifat gambar dan relasinya (Muslim et al., 2017; Rinaldi et al., 2019; dan Dewi 2019).

\section{Kesimpulan}

Berdasarkan hasil analisis dan pembahasan, saat memahami masalah siswa cenderung mengalami asimilasi saat menjelaskan maksud permasalahan, dan akomodasi saat menjelaskan data apa saja yang belum diketahui. Saat menyusun rencana, peristiwa asimilasi dan akomodasi berlangsung ketika siswa mencoba menentukan alur penyelesaian masalah. Pada tahap melaksanakan rencana, siswa cenderung mengalami proses asimilasi pada soal pertama, dan cenderung mengalami akomodasi pada soal nomor 2. Terakhir yaitu tahap memeriksa kembali, siswa awalnya cenderung berada pada kondisi disequilibrium kemudian berakomodasi untuk memeriksa jawaban. Akhirnya siswa mengalami equilibrium dibuktikan dengan siswa mampu menyelesaikan masalah dengan baik dan telah memenuhi indikator van Hiele. 


\section{Daftar Pustaka}

Agostino, S. D. (2011). A math major, polya, invention, and discovery. Journal of Humanistic Mathematics, 1(2), 51-55.

Asemani, E., Asiedu-Addo, S. K., \& Oppong, R. A. (2017). The Geometric Thinking Levels of Senior. International Journal of Mathematics and Statistics Studies, 5(3), 1-8.

Ayuningrum, D. (2017). Strategi Pemecahan Masalah Matematika Siswa SMP Ditinjau Dari Tingkat Berpikir Geometri Van Hiele. Kreano, Jurnal Matematika Kreatif-Inovatif, 8(1), 27-34. https:/ / doi.org/ 10.15294/ kreano.v8i1.6851

Dewi, N. S. (2019). Proses Berpikir Siswa Level Deduksi Dalam Membuktikan Teorema Kesebandingan Segitiga dan Konversinya Berdasarkan Langkah-langkah Polya. In Fakultas Keguruan dan Ilmu Pendidikan Universitas Jember.

Fabiyi. (2017). Geometry Concepts in Mathematics Perceived Difficult To Learn By

Senior Secondary School Students in Ekiti State, Nigeria. IOSR Journal of Research \& Method in Education (IOSRJRME), 07(01), 83-90. https:// doi.org/ 10.9790/ 7388-0701018390

Falupi, D. V., \& Widadah, S. (2016). Profil Berpikir Geometris Pada Materi Bangun Datar Ditinjau Dari Teori Van Hiele. Jurnal Pendidikan Matematika STKIP PGRI Sidoarjo, 4(1), 1-8.

Fitriyani, H., Widodo, S. A., \& Hendroanto, A. (2018). Students' Geometric Thinking Based on Van Hiele's Theory. Infinity Journal. https:// doi.org/ 10.22460/ infinity.v7i1.p55-60

Hadi, A. M. (2019). Analisis Proses Pembelajaran Matematika Anak Berkebutuhan Khusus (ABK) Dalam Memahami Bangun Datar Berdasarkan Teori Van Hiele Di Smplb Bd Kota Bima. Prosiding Silogisme, 1(1), 24-33.

Hiele, P. M. Van. (2000). Developing Geometric Thinking through Activities that Begin with Play. Teaching Children Mathematics, 6(February 1999), 310-316.

Jayathirtha, G. (2018). An Analysis of the National Intended Geometry Curriculum. Contemporary Education Dialogue. https:// doi.org/ 10.1177/ 0973184918783291

Kivkovich, N. (2015). A tool for solving geometric problems using mediated mathematical discourse (for Teachers and Pupils). Procedia - Social and 
Behavioral

Sciences,

209,

$519-525$.

https:/ / doi.org/ 10.1016/ j.sbspro.2015.11.282

McLeod, S. A. (2018). Piaget's Theory of Cognitive Development.

Muslim, A. (2017). Proses Berpikir Kritis Siswa pada Level Deduksi Informal van

Hiele. Conferences Uin Malang, 1(1), 86-94.

http:/ / conferences.uin-malang.ac.id/ index.php/ SIMANIS/ article/ view/ 42

Pavlovicova, G., \& Zahorska, J. (2015). The Attitudes of Students to the Geometry and

Their Concepts about Square. Procedia - Social and Behavioral Sciences, 197, 1907-1912. https:/ / doi.org/ 10.1016/ j.sbspro.2015.07.253

POLYA, G. (2020). Physical Mathematics. In Mathematics and Plausible Reasoning, Volume 1. https:/ / doi.org/ 10.2307/ j.ctv14164db.13

Pressley, A. (2010). Elementary differential geometry. 2nd ed. Springer. https:/ / doi.org/ 10.1007/ 978-1-84882-891-9

Ramdani, Y. (2012). Pengembangan instrumen dan bahan ajar untuk meningkatkan kemampuan komunikasi, penalaran, dan koneksi matematis dalam konsep integral. Jurnal Penelitian Pendidikan, 13(1), 44-52. http:/ / jurnal.upi.edu/ file/ 6-yani_ramdhana-edi.pdf

Rinaldi, E. N. Z., Supratman, \& Hermanto, R. (2019). Proses Berpikir Peserta Didik Ditinjau Dari Kemampuan Spasial Berdasarkan Level Berpikir van Hiele. Journal of Authentic Research on Mathematics Education, 1(1), 38-45.

Setyawan, D. (2019). Eksplorasi Proses Konstruksi Pengetahuan Materi Bangun Ruang Siswa dengan Gaya Berpikir Acak dan Kemampuan Keruangan Level Rotasi Mental. 19(April 2019), 78-84.

Siegler, R., DeLoache, J., Eisenberg, N., \& Saffran, J. (2014). Theories of Cognitive Development. How Children Develop. https:// doi.org/ 10.5901/ jesr.2015.v5n1p313

Usiskin, Z. (1982). Van Hiele Levels and Achievement in Secondary School Geometry. CDASSG Project. Chicago University.

Walle, J. A. Van De, Karp, K. S., \& Wray, J. (2016). Elementary and Middle School Mathematics Teaching Developmentally 9th Edition. Pearson Education.

Yuan, S. (2013). Incorporating Polya's problem solving method in remedial math. Journal of Humanistic Mathematics, 3(1), 96-107.

Yudianto, E., Trapsilasiwi, D., Sunardi, Suharto, Susanto, \& Yulyaningsih. (2019). The process of student's thinking deduction level to solve the problem of geometry. 
Journal of Physics: Conference Series, 1321(2). https:/ / doi.org/ 10.1088/ 1742-6596/ 1321/ 2/ 022078

Yudianto, Erfan, Sunardi, Sugiarti, T., Susanto, Suharto, \& Trapsilasiwi, D. (2018). The identification of van Hiele level students on the topic of space analytic geometry. Journal of Physics: Conference Series, 983(1), 1-5. https:/ / doi.org/ 10.1088/ 1742-6596/ 983/ 1/ 012078 